\title{
POLSKA NAUKA 0 ARCHIWACH WOBEC NAUKI O DOKUMENCIE ORAZ ROZWOJU INTER-, MULTI- I TRANSDYSCYPLINARNOŚCI
}

Słowa kluczowe: interdyscyplinarność, filozofia nauki, Tadeusz Grygier, Sue McKemmish, Anne J. Gilliland, Luciana Duranti, Livia Iacovino

\section{Streszczenie}

Artykuł to dyskurs proponujący jeden z kierunków, w których może podążać polska archiwistyka, by szerzej wkroczyć w nowoczesną interdyscyplinarność. W części pierwszej wskazano, że ogólne ramy tworzą do tego ujęcia z filozofii nauki oraz nowy podręcznik oksfordzki. Wzięto też pod uwagę dyskusje polskich filozofów, politologów, pedagogów i innych analizujących rozmaite odmiany interdyscyplinarności. Z podręczników archiwistyki wydobyto głównie refleksje nad jej zakresem oraz relacjami z innymi naukami, zwracając szczególną uwagę na koncepcje Tadeusza Grygiera.

Część druga, to wstępna próba rozpoznania pewnych kierunków rozwoju interdyscyplinarności, zwłaszcza w obu archiwistykach północnoamerykańskich oraz australijskiej, w poszukiwaniu ewentualnych inspiracji dla polskiej nauki o archiwach. Ogólny obraz starano się uzyskać z wybranych prac Sue McKemmish i Anne J. Gilliland i innych, ze skupieniem się na znaczeniu dowodowości jako podstawowej cechy dokumentacji interesującej archiwistów i records managerów.

Z kolei zajęto się artykułem Livii Iacovino z 2004 r. Wydobyto wątek o konieczności odnowienia silnych więzi nauki o archiwach z naukami prawnymi. Do tego nawołuje Luciana Duranti, uznająca prymarne znaczenie dyplomatyki dla archiwistyki. Autor zgadza się z tymi poglądami, przypominając o swej propozycji, by ośrodkiem koncepcji kształcenia archiwistów i records managerów uczynić zjawisko dokumentu. Wskazano również na najciekawsze przykłady archiwistycznej interdyscyplinarności anglosaskiej. 
KRZYSZTOF SKUPIEŃSKI

ORCID 0000-0002-3581-7753

krzysztof.skupienski@umcs.pl

(Maria Curie-Skłodowska University in Lublin)

\title{
POLISH ARCHIVAL SCIENCE VERSUS DOCUMENTARY SCIENCE AND DEVELOPMENT OF INTER-, MULTI- AND TRANSDISCIPLINARITY
}

Keywords: interdisciplinarity, philosophy of science, Tadeusz Grygier, Sue McKemmish, Anne J. Gilliland, Luciana Duranti, Livia Iacovino

\begin{abstract}
The article is a discourse, proposing one of directions that Polish archival science might take in order to make a broader foray into the modern interdisciplinarity. In the first part, the general framework is indicated, based on philosophy of science and the new Oxford manual. Discussions of Polish philosophers, political scientists, pedagogists, and others analysing various types of interdisciplinarity were taken into account. Archivistics textbooks were the source for, mainly, reflection on its scope and relationship with other sciences, with particular focus on Tadeusz Grygier's concepts.

The second part is an initial attempt to recognize certain directions of interdisciplinarity development, in particular in both North American, and Australian branches of archival science, in search for potential inspirations for Polish archival science. An attempt is made to derive a general view from selected works by Sue McKemmish and Anne J. Gilliland et al., with focus on importance of evidentiary value as the main feature of documentation to be of interest to archivists and records managers.

Subsequently, Livia Iacovino's 2004 article was analysed. Emphasis was put on the topic of need to renew strong ties between archival science and legal sciences. Luciana Duranti also calls for that, recognizing diplomacy's primary importance for archival science. The author agrees with those views, reiterating his proposal to place the document as a phenomenon at the centre of archivists and record managers education concept. Some of the most interesting examples of archival interdisciplinarity in Anglo-Saxon countries are also presented.
\end{abstract}




\section{Część pierwsza}

Artykuł stanowi raczej wyraz subiektywnych poglądów, niż studium wszystkich zagadnień, omawianych w polskiej i zagranicznej literaturze przedmiotu w związku z kwestią interdyscyplinarności nauki o archiwach. Słowo ,interdyscyplinarność" stało się dzisiaj już bardzo popularne, w kręgach naukowych. W latach 2011-2018 częstotliwość jego używania na łamach „Archeionu” była niemal dwukrotnie wyższa niż w latach 1995-2010 (z 2,4 przypadków na numer do 4,6) ${ }^{1}$. Zwykle nieźle zdajemy sobie sprawę z tego, o co w nim idzie. Ogólnie biorąc - to myślenie ponad granicami dyscyplin akademickich. Szczególnie zainteresowani są tym przedstawiciele nauk społecznych oraz humanistycznych.

Archiwista, zwłaszcza badacz, obok uprawiania swoich pól poznawczych, powinien umieć zabrać głos $\mathrm{w}$ dyskusjach prawników i administratywistów, a także znawców nauk o zarządzaniu i organizacji, jak również o informacji i komunikacji i in. Interdyscyplinarność może też oznaczać współpracę praktyków - inżynierów lub innych fachowców różnych specjalności. Archiwiści praktycy często muszą korzystać z ich wiedzy technicznej, biologicznej, materiałoznawczej itp. Czasem interdyscyplinarność wypływa z niepokojów związanych z postępami specjalizacji w nauce. Zwięźle i z ironią ujął to znany hiszpański filozof: „Specjalista »wie« wszystko o swoim malutkim wycinku wszechświata, ale co do całej reszty jest absolutnym ignorantem"2. Interdyscyplinarność ma zatem dostarczać wiedzy, ale bez cudzysłowu. Od dłuższego czasu mamy do czynienia w świecie z intensywnym rozwojem studiów nie tylko interdyscyplinarnych, ale też nad samą interdyscyplinarnością. Dawno wykroczyły one poza stadium intuicyjnego pojmowania zjawiska. Szerokim nurtem toczą się dyskusje o jego epistemologicznych podstawach, historii, istocie itp. Powstają centra badań, jak np. „International Network for Interdisciplinarity \& Transdisciplinarity”3. Interdyscyplinarne prądy badawcze - au rebours - muszą zajmować się także „dyscyplinarnością", czyli kwestią, czym są dziś istniejące dyscypliny naukowe.

${ }^{1}$ Dodajmy do tego chyba jedyne dwa teksty archiwistyczne, gdzie słowo to pojawiło się w tytule polskiej pracy archiwistycznej: S. Sierpowski, Interdyscyplinarna archiwistyka, „Archeion” 2003, t. 105, s. 42-45; H. Mazur, Między dydaktyka a archiwistyka - interdyscyplinarność archiwistyki w kontekście edukacyjnej funkcji archiwów, [w:] Nowa archiwistyka - archiwa i archiwistyka w ponowoczesnym kontekście kulturowym, Toruńskie Konfrontacje Archiwalne, t. 4, red. W. Chorążyczewski, W. Piasek, A. Rosa, Toruń, 2014, s. 163-187. Ukazał się kolejny tom z cyklu Toruńskie Konfrontacje Archiwalne, t. 6, Pogranicza archiwistyki (red. W. Chorążyczewski, A. Rosa, Toruń 2019), gdzie uwagę przyciąga artykuł: W. Piasek, Archiwistyka - jedna czy wiele dyscyplin naukowych? Uwagi z perspektywy ,,nowej archiwistyki”, s. 25-31, oraz teksty W. Kwiatkowskiej, P. Bewicza i A. Bialiauskiego.

2 J. Ortega y Gasset, Bunt mas, przeł. P. Niklewicz, Warszawa 2002, s. 35, https://filspol.files. wordpress.com/2009/10/ortega-y-gasset-jose-bunt-mas.pdf [dostęp: 29.08.18].

${ }^{3}$ http://www.inidtd.org/ [dostęp: 25.09.2018]. 
Uzyskanie uniwersalnej perspektywy, to zadanie zwłaszcza dla filozofii nauki, jak widać na przykładzie pracy, która mówi o strukturze wiedzy interdyscyplinarnej ${ }^{4}$. Zajął się tą kwestią również filozof francuski Jacques Rancière przy okazji rozmyślań nad estetyką wiedzy, które prowadził ,pomiędzy dyscyplinami”. Zainteresował się istotą dyscyplin naukowych. „It is to recall that a discipline is always much more than an ensemble of procedures which permit the thought of a given territory of objects. It is first the constitution of this territory itself, and therefore the establishment of a certain distribution of the thinkable. As such, it supposes a cut in the common fabric of manifestations of thought and language"'5. Widać tu znaczny poziom abstrakcyjności myślenia, o tym co niekiedy nazywa się $A$-disciplinarity ${ }^{6}$.

Dla wstępnej orientacji godny polecenia jest oxfordzki podręcznik interdyscyplinarności ${ }^{7}$. Daje on porównawczy przegląd bieżącego stanu interdyscyplinarnych badań, edukacji i działań administracyjnych. Praca ma 41 rozdziałów. Oto tytuły chyba interesujące dla archiwistów: Integracja nauk społecznych: badania terenowe, metody kwantytatywne i badania problemowe; Interdyscyplinarne nauki humanistyczne; Humanistyka cyfrowa: rola interdyscyplinarnych nauk humanistycznych w epoce informacji; Interdyscyplinarność na polach prawa, sprawiedliwości i kryminologii. Badania nad informacją ku interdyscyplinarności.

Sporo światła na potencjał interdyscyplinarności archiwistyki rzucają dyskusje, jakie toczą się w polskiej humanistyce i naukach społecznych itp. Jan Woleński zajął się interdyscyplinarnością w związku z integracją zewnętrzną i wewnętrzną nauk ${ }^{8}$. Na przykładach $\mathrm{z}$ wybranych dyscyplin mamy tu porównanie integracji nauk z interdyscyplinarnością. Granicy między nimi nie da się dokładnie określić, choć według autora, to pierwsze ma większe znaczenie w nauce niż to drugie. Integracja polega „na zespoleniu wyników czy metod pochodzących z rozmaitych dyscyplin naukowych w nowe dyscypliny", jak np. fizykochemia czy lingwistyka kognitywna.

Politolog Maciej Karczewski też pisze o interdyscyplinarności. „Współcześnie ten bardzo modny termin odmieniany jest przez wszystkie przypadki niczym mantra. Osiągnął wręcz status zaklęcia automatycznie nadającego poszczególnym projektom naukowym waloru nowoczesności i innowacyjności”. Autor przytacza dalej opinię Mirosława Karwata, uważającego, że ,politologia

\footnotetext{
${ }^{4}$ R. Hvidtfeldt, The Structure of Interdisciplinary Science, Cham 2018.

5 J. Rancière, Thinking between disciplines: an aesthetics of knowledge, transl. J. Roffe, „Parrhesia” 2006, nr 1, s. 1-12, (cytat ze s. 8), https://www.parrhesiajournal.org/parrhesia01/parrhesia01_ranciere.pdf [dostęp: 25.09.2018].

${ }^{6}$ Zob. np.: https://arthist.net/archive/6491 [dostęp: 25.09.2018].

7 The Oxford Handbook of Interdisciplinarity, ed. by R. Frodeman, Oxford 2019.

8 J. Woleński, O wewnętrznej i zewnętrznej integracji nauk, „Zagadnienia Naukoznawstwa” 2016, t. 52, z. 1, s. 5-14, https://www.infona.pl/resource/...374b.../f77c03c8-b28e-31da-a9f6-f0a0ffd065e2 [dostęp: 29.08.2018].
} 
jest multidyscyplinarną rodziną nauk"9. Wskazuje on na niemożliwość jasnego zdefiniowania obiektu badań przynależnego tylko do politologii. Granice obiektów badań humanistycznych i społecznych krzyżują się, nie pozwalając na ich dokładne oddzielanie. Następnie mamy omówienie przeciwnego poglądu Ryszarda Skarzyńskiego. Sądzi on, że bez wyodrębnienia przedmiotu badań nie można w ogóle mówić o dyscyplinie naukowej. Oczywiście należy też wykorzystywać dorobek innych nauk, zwłaszcza różnych tzw. dyscyplin pomocniczych itp.

Ważny wydaje się też artykuł dotyczący tzw. studiów wizualnych. Autorka Justyna Tabaszewska, uznając słabości koncepcji interdyscyplinarności, na plan pierwszy wysuwa konstrukt transdyscyplinarności $i^{10}:,[\ldots]$ o ile interdyscyplinarność bada pogranicza dyscyplin, czerpiąc z niesprzecznych ze sobą metodologii, o tyle transdyscyplinarność zajmuje się raczej tymi obszarami, których przyporządkowanie do określonej dyscypliny nie jest jednoznaczne albo które nie dają się objąć za pomocą podziałów między poszczególnymi dyscyplinami”"1. Kolejnym przykładem testowania koncepcji transdyscyplinarności jest trzytomowe zbiorowe wydawnictwo poświęcone jej zastosowaniu do badań nad komunikacją medialną ${ }^{12}$.

Warto też wskazać na artykuł poświęcony pojmowaniu interdyscyplinarności w obrębie nauk o edukacji ${ }^{13}$. Autor, będący filozofem wychowania, prezentuje szeroką panoramę problemów. Omawia koncepcje interdyscyplinarności, transdyscyplinarności oraz multidyscyplinarności. Wszystkie zrodziła „współczesna potrzeba poszukiwania połączeń i obszarów współdziałania poszczególnych dyscyplin nauki jako reakcja na partykularyzację i atomizację dziedzin wiedzy [...] Problem nie polega zatem na konieczności [...] wspierania idei integracji dyscyplinarnych wyników badań. To, co rodzi dyskusje [...] polega bowiem na sposobie dookreślania samej relacji współdziałania i współzależności, stop-

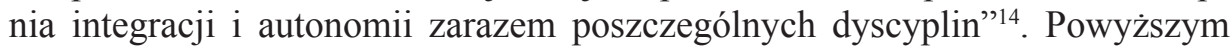

${ }^{9}$ M. Karczewski, Czy politologia to „,nauka interdyscyplinarna”? Kilka slów o przedmiocie poznania i tożsamości dyscypliny, „Refleksje” 2013, nr 7, s. 159-170, https://repozytorium.amu.edu.pl/ bitstream/10593/10526/1/Maciej\%20Karczewski.pdf [dostęp: 27.08.2019].

10 J. Tabaszewska, ,Wędrujące pojęcia”. Koncepcja Mieke Bal - przyktad inter-czy transdyscplinarności?, „Studia Europaea Gnesnensia” 2013, t. 8, s. 113-130, http://bazhum.muzhp.pl/ media//files/Studia_Europaea_Gnesnensia/Studia_Europaea_Gnesnensia-r2013-t8/Studia_Europaea_Gnesnensia-r2013-t8-s113-130/Studia_Europaea_Gnesnensia-r2013-t8-s113-130.pdf [dostęp: 25.08.2018].

${ }^{11}$ Ibidem, s. 117-118.

12 Transdyscyplinarność badań nad komunikacja medialna, red. M. Kita, M. Ślawska, t. 1-3, Katowice 2012-2013.

${ }_{13} \mathrm{~J}$. Gara, Idea transcyscyplinarności i interdyscyplinarna natura wiedzy pedagogicznej, „Forum Pedagogiczne" 2014, nr 1, s. 35-54, http://bazhum.muzhp.pl/media//files/Forum_Pedagogiczne/Forum Pedagogiczne-r2014-t1/Forum Pedagogiczne-r2014-t1-s35-54/Forum_Pedagogiczne-r2014-t1-s35-54.pdf [dostęp: 01.09.2018].

${ }^{14}$ Ibidem, s. 36 , przyp. 3. 
nurtom przeciwstawia się unidyscyplinarność. Uważa, że tamte prowadzą do „rozmywania się granic tradycyjnych dyscyplin i »kakofonii języków teoretycznych «, a co za tym idzie kryzysu i upadku idei interdyscyplinarności”"15.

Mamy więc do czynienia ze złożonością sposobów myślenia o przekraczaniu granic dyscyplin naukowych. Tego oczywiście nie da się zawrzeć w jednym artykule. Przejdźmy więc do polskiej archiwistyki. Na pierwszy rzut oka jej teoretycy, zwłaszcza chyba Kazimierz Arłamowski, bardziej troszczyli się o utrzymywanie się w obrębie samej istoty archiwistyki niż o wychodzenie poza granice. Chodziło o obszar, wewnątrz którego archiwiści mogą liczyć na swe kompetencje twarde, związane bezpośrednio z posiadanymi kwalifikacjami zawodowymi. Wydaje się to postawą podzielaną przez znaczną część archiwistów praktyków.

Jednak z drugiej strony, można by się pokusić o przypuszczenie w stylu archiwozofii - czy też raczej wprowadzonej u nas przez Tadeusza Grygiera, ,filozofii archiwalnej”'16 - że archiwistyka może stać się nauką poniekąd ogarniającą myślenie o wielu aspektach obecnych w polach widzenia wielu dziedzin i dyscyplin. Argumentów może tu dostarczyć np. spostrzeżenie, że w sensie najogólniejszym, zawsze gdy przechowuje się dane, informacje, dokumentację czy np. wiedzę, mamy do czynienia $\mathrm{z}$ archiwizowaniem.

W polskiej literaturze archiwistycznej rzadko używano terminu ,interdyscyplinarność". Podnoszono problematykę z nią związaną przy omawianiu kwestii takich jak: tożsamość nauki o archiwach, jej przedmiot dociekań, cel badawczy oraz zakres rzeczowy i chronologiczny itp. Prace tego rodzaju mają ponad 30 lat ${ }^{17}$, jednak wciąż chyba tworzą zasadniczy układ odniesień dla teoretyzującego myślenia o naszej dyscyplinie.

Największy wpływ zapewne wywierają przemyślane poglądy Bohdana Ryszewskiego. Ponowna ich lektura dostarcza inspiracji skłaniających do świeżego przemyślenia niektórych kwestii. „Archiwistyka [...] styka się z różnymi dyscyplinami, a niekiedy penetruje wspólnie z nimi pewne obszary problemowe $[\ldots]$ Są to związki $[\ldots]$ wzajemnie korzystne $[\ldots]$ trzeba je rozwijać" ${ }^{18}$. Na czoło został tu wysunięty problem badania akt i kancelarii. Warto tu dodać, że niekiedy uznaje się go po prostu za część nauki o archiwach albo też za obiekt

\footnotetext{
${ }^{15}$ Ibidem, s. 37.

16 Jest ono starsze od archiwozofii, pojęcia wprowadzonego przez Dariusza Magiera, idem, Czas archiwozofii, [w:] Teoria archiwalna wczoraj - dziś - jutro, Toruńskie Konfrontacje Archiwalne, t. 2, red. W. Chorążyczewski, A. Rosa, Toruń 2011, s. 9-20. Podobne określenie „filozofia archiwum” jest znane w archiwistyce światowej. M.in. stało się ono hasłem konferencji w Edynburgu w 2008 r. - zob. jej materiały składające się z dziewięciu tekstów: „Archival Science”, vol. 9, Issue 3-4, December 2009 (Special Issue: The Philosophy of the Archive. Papers from the Conference held in Edinburgh, 10-11 April, 2008, guest editors P. Whatley and C. Brown).

${ }^{17}$ W zasadzie aktualny pozostaje zestaw pozycji zamieszczony w: H. Robótka, B. Ryszewski, A. Tomczak, Archiwistyka, Warszawa 1989, s. 8, łącznie z jego źródłem. Zob. też niżej przyp. 18, 22, 23.

${ }^{18}$ B. Ryszewski, Problemy i metody badawcze archiwistyki, Torun 1985, s. 15.
} 
dociekań dyplomatyki klasycznej, ale też dyplomatyk - nowożytnej, najnowszej i in., a także cyfrowej ${ }^{19}$. Ryszewski uznaje raczej pogląd, że w tym wypadku chodzi o aktoznawstwo, ujmowane w kategoriach formalnej genetyki i klasyfikacji akt na wzór Aktenkunde Heinricha Ottona Meissnera. Zdaniem Ryszewskiego, z którym w tym punkcie nie ma zgody, aktoznawstwo ma rozleglejszy zasięg badań od „dawnej dyplomatyki”. Zaznaczony został także udział nauk pomocniczych historii, głównie w sferze źródłoznawstwa. Na samym zaś końcu listy dyscyplin łączących się z archiwistyką, Ryszewski stwierdza „trwałość [jej] związku z naukami historycznymi" ${ }^{20}$. Zwraca uwagę, że brak szerszej wzmianki o znaczeniu krytyki źródeł historycznych dla zrównoważonej oceny formy i treści archiwaliów, a w konsekwencji selekcji archiwaliów przechowywanych wieczyście. Następnie wskazano na historię ustroju szczególnie administracyjnego, a także prawoznawstwo administracyjne. Na kolejnym miejscu omówiono związek z naukami o organizacji i zarządzaniu. Dostarczają one m.in. wiedzy o organizacji pracy grup ludzi. Dalej Ryszewski wskazuje, że archiwistyka należy też do systemu nauk o komunikacji społecznej. Wśród nich na czoło autor wysuwa informację naukową, której archiwistyka ,jest podporządkowana" ${ }^{21}$. Notabene to drugie dziś wydaje się nieco przesadne. Wreszcie mamy wskazanie na znaczenie powiązań archiwistyki z cybernetyką oraz naukami systemowymi.

Szczególnie interesujące są koncepcje Kazimierza Arłamowskiego, Czesława Biernata oraz Tadeusza Grygiera. O podejściu Kazimierza Arłamowskiego do kwestii interdyscyplinarności archiwistyki (który nb. nie użył tego terminu w swym tekście z 1970 r.) sporo mówi cytat: „Z przedmiotowego zakresu archiwistyki wyłączam w dalszym ciągu historię ustroju, historię kancelarii i organizację biurowości. Stoję bowiem na stanowisku, że do zakresu archiwistyki należy nie to, czym się rzeczywiście zajmują archiwiści na marginesie wykonywanych prac archiwalnych, lecz to, co się bezpośrednio łączy z archiwami $\mathrm{i}$ ich zasobem, tj. z zespołami archiwalnymi i nie stanowi przedmiotu odrębnych wyspecjalizowanych dyscyplin"22.

W 1977 r. ukazała się książka Czesława Biernata, będąca wykładem ,problemów teoretycznych i rozwiązań praktycznych, stosowanych w archiwistyce"23. Pierwszy akapit podrozdziału o zakresie archiwistyki nosi tytuł Rozgraniczenia interdyscyplinarne. W naszej literaturze archiwistycznej przymiotnik ten pojawia się, jeśli nie pierwszy raz, to na pewno wcześnie. „Przedmiot archiwistyki

${ }^{19}$ K. Skupieński, Pytania o „causae bellicorum diplomaticorum” w XXI wieku. Od dyplomatyki mediewistycznej do Records Management, [w:] Belliculum diplomaticum VI Thorunense. Od dyplomatyki i archiwistyki do dokumentu elektronicznego, pod. red. K. Kopińskiego i J. Tandeckiego, Toruń 2016, s. 83-103.

${ }^{20}$ B. Ryszewski, op.cit., s. 19.

${ }^{21}$ Ibidem, s. 19.

${ }^{22}$ K. Arłamowski, Archiwistyka, jej natura i definicja, ,Archeion” 1970, t. 53, s. 15.

${ }^{23}$ Cz. Biernat, Problemy archiwistyki wspótczesnej, Warszawa 1977, s. 3. 
może być rozpatrywany z różnych punktów widzenia, m.in. na podstawie zakresu gromadzenia dokumentacji archiwalnej i przedmiotu badań naukowych"24. W tej drugiej perspektywie trzeba podjąć problem rozgraniczeń „między archiwistyką i innymi pokrewnymi dyscyplinami”, co jest kwestią bardziej złożoną niż ta pierwsza. Biernat przedstawia owe dyscypliny pokrewne, zaczynając od powiązanej z nią „bardzo wyraźnie” dyplomatyki. Na drugim miejscu mamy naukę o organizacji i zarządzaniu, następnie informatykę oraz nauki pomocnicze historii. Jak widać chodzi o dyscypliny bliskie archiwistyce - albo genetycznie, albo przedmiotowo.

Inne podejście w tej kwestii zaprezentował Tadeusz Grygier. Interesująco stosował koncepcję filozofii archiwalnej. Pojmował interdyscyplinarność archiwistyki w sposób specyficzny, co jest bardzo inspirujące. W wielu kwestiach należy się zgodzić z jego punktem widzenia. Brak miejsca na szersze omówienia niech zilustruje cytat: „Tymczasem celem podstawowym zarządu aktami2 ${ }^{25}$ jest interdyscyplinarne ujmowanie akt i spraw" ${ }^{26}$. Dorobek tego innowacyjnego teoretyka i „filozofa archiwalnego" powinien być szerzej uwzględniany w refleksji o kondycji polskiej archiwistyki.

\section{Częséć druga}

Przyjrzenie się niektórym ogólnym podejściom do rozmaicie nazywanej kwestii przekraczania granic między dyscyplinami, jak również rzut oka na polską literaturę archiwistyczną, skłania do pewnych przemyśleń. Na czoło wysuwa się potrzeba rozpoznania, jak problematyka interdyscyplinarności nauki o archiwach jest traktowana za granicą. Chodzi o rozpoznanie skali i kierunków rozwoju tych zjawisk. Intersujące wydają się przede wszystkim syntetyczne publikacje anglosaskie, napisane głównie przez badaczy północnoamerykańskich ${ }^{27}$ oraz australijskich. Krótka charakterystyka wybranych tekstów przybliży tematykę.

Publikacja Metody badawcze: informacja, systemy, konteksty z 2013 r. ${ }^{28}$, to podręcznik dla menedżerów informacji, bibliotek, archiwów oraz systemów zapisów (records). Rozdział czwarty poświecono archiwom. Nosi tytuł Badania archiwalne, a także nad prowadzeniem dokumentacji: przeszłość, teraźniejszość i przyszłość ${ }^{29}$. Jego autorkami są: Sue McKemmish, z uniwersytetu Monash

\footnotetext{
${ }^{24}$ Ibidem, s. 38.

${ }^{25}$ Tak autor spolszczył termin Records Management. Zob.: T. Grygier, Zarzad aktami - problem centralny archiwistyki współczesnej, „Archiwa, Biblioteki i Muzea Kościelne” 1978, t. 36, s. 21-59.

${ }^{26}$ Ibidem, s. 29.

${ }^{27}$ W pracy Bartosza Nowożyckiego, Teoria i praktyka archiwistyki USA (Warszawa 2017), ku pewnemu rozczarowaniu, nie ma ani jednego przypadku słowa ,interdyscyplinarność” i od niego pochodnych.

${ }^{28}$ Research Methods: Information, Systems and Contexts, red. K. Williamson, G. Johanson, Prahran 2013.

${ }^{29}$ Archival and recordkeeping research: past, present and future, ibidem, s. 79-112.
} 
w Melbourne, oraz Anne J. Gilliland, z University of California w Los Angeles. Dokonują one przeglądu badań tego rodzaju z ostatniego ćwierćwiecza. Przyjmują, że oba te określenia obejmują pełną perspektywę wszystkich punktów, z których możemy obserwować zjawiska zachodzące zarówno w tradycyjnym modelu cyklu życia zapisów (dokumentacji), jak i w nowszym modelu ich continuum. Jak widać, chodzi tu o spojrzenie przez pryzmat szeroko rozumianych kategorii pojęciowych. Obejmują one także prace badawcze w ramach dziedzin pomocniczych, służebnych oraz komplementarnych wobec archiwistyki i zarządzania dokumentacją. To pogląd wydatnie poszerzający granice obu dyscyplin ze znacznym wykroczeniem poza rubieże tradycyjnego ich centrum. Odwołują się do artykułu o kształceniu dla potrzeb archiwalnego wieloświata ${ }^{30}$ (archival multiverse), dosłownie przytaczając $\mathrm{z}$ niego określenie tego pojęcia: „Term is particularly resonant and encompasses the pluralism of evidentiary texts, memory-keeping practices and institutions, bureaucratic and personal motivations, community perspectives and needs, and cultural and legal constructs with which archival professionals and academics must be prepared, through graduate education, to engage" ${ }^{\prime 1}$. Tekst artykułu stanowi zapis wniosków z prac dwóch zespołów, zajmujących się problemami edukacji archiwistycznej z zamiarem wywołania dyskusji nad szerokim kręgiem zagadnień, często związanych z koncepcjami postmodernizmu. Ich dalsze rozwinięcie nie tak dawno przybrało postać prawie tysiącstronicowego tomu ${ }^{32}$. Pojawiła się też tam silna zachęta do podejść interdyscyplinarnych przy układaniu programów studiów archiwistycznych. Chodzi zarówno o dyskutowanie kwestii archiwistycznych ze specjalistami innych dyscyplin, jak i o wykorzystywanie w archiwistyce koncepcji przez nich stworzonych. Wymieniono m.in.: kulturoznawstwo, studia postkolonialne, etniczne i gender study. Wracając do przytoczonego już wyjaśnienia terminu archival multiverse, warto zwrócić uwagę na określenie „the pluralism of evidentiary texts”. Zastosowano ten właśnie termin, aby objąć nim dokumenty czy raczej zapisy (records) z uwagi na fakt, że występują one w wielu kontekstach kulturowych jako zapisy społeczne, odnoszące się wyłącznie do instytucjonalnych albo biurokratycznych form prowadzenia i przechowywania dokumentacji. Można zatem sądzić, że zdaniem autorek chodzi tu o nadrzędną cechę wszelkiej dokumentacji - bieżącej i przechowywanej czasowo, a chyba także wieczyście. Stanowi ona mianowicie teksty dowodowe. Słuszne jest zatem opowiedzenie się za przyjęciem takiego

${ }^{30}$ Przyjęto tu propozycję polskiej nazwy ze wzbudzającego zaufanie hasła w Wikipedii, https:// pl.wikipedia.org/wiki/Wielo\%C5\%9Bwiat [dostęp: 20.11.2018].

${ }^{31}$ Educating for the Archival Multiverse. The Archival Education and Research Institute (AERI), Pluralizing the Archival Curriculum Group (PACG), „The American Archivist”, vol. 74 (Spring/Summer 2011), s. 73, http://americanarchivist.org/doi/10.17723/aarc.74.1.hv33964712745684 [dostęp: 25.11.2018].

${ }^{32}$ Research in the Archival Multiverse, ed. by A.J Gilliland, S. McKemmish, A.J. Lau, Monash University Publishing 2017, https://www.oapen.org/download?type=document\&docid=62814 [dostęp: 10.09.2018]. 
właśnie punktu widzenia jako centrum, wokół którego należy budować dydaktyczne jak również naukowe konstrukcje związane z archiwistyką oraz zarządzaniem dokumentacją ${ }^{33}$.

Jeśli chodzi o wspomnianą ocenę rozwoju badań archiwistycznych oraz z zakresu prowadzenia i przechowywania dokumentacji na całym świecie w ostatnim ćwierćwieczu przed rokiem 2013, to McKemmish i Gilliland uważają, że nastąpił wówczas bezprecedensowy rozwój połączony z niespotykanym wcześniej zróżnicowaniem tematów badawczych. Przyczyniło się do tego także poszerzenie frontu badawczego i rozwój szerokiej, często międzynarodowej, współpracy środowisk archiwistycznych oraz zajmujących się prowadzeniem dokumentacji z badaczami innych dyscyplin, sferami rządowymi, biznesowymi, a także organizacjami typu non-profit i społecznymi. Ten rozwój zilustrowano za pomocą trzech tablic katalogujących tematykę badań archiwistycznych podejmowaną w latach 1998, 2004 i 2009-2012. Autorki je charakteryzują. Tu musi wystarczyć krótka egzemplifikacja. Większość nowych kierunków badawczych eksploruje pola wykorzystywania ICT, zwłaszcza w takich zakresach, jak archiwizowanie danych. Poza tym chodzi np. o kwestie archiwizacji pamięci oralnej aborygenów w Australii. Ma to związek z postrzeganiem archiwów jako ważnych instrumentów sprawiedliwości społecznej, często w związku z postkolonializmem. W zakresie teorii archiwalnej trzeba wymienić próby nowego spojrzenia na kwestie wartościowania archiwaliów. To m.in. odpowiedź na refleksje Hansa Boomsa i innych na temat tego rodzaju problematyki w odniesieniu do komunizmu i rozwoju teorii społecznej ${ }^{34}$. Innymi ciekawymi przykładami poszerzania perspektyw badawczych mogą być badania: nad tożsamością i pamięcią, nad zjawiskami dowodowości, nad archiwaliami w muzeach, nad kwestiami życia społecznego zapisów i dokumentów, nad dokumentacją stanu zdrowia itd. Rysuje się więc obraz nauk o archiwach oraz o dokumencie jako wielowymiarowych dyscyplin społecznych i humanistycznych, szerokim frontem wkraczających na terytoria wielu innych dyscyplin.

Innym inspirującym przykładem może być artykuł Livii Iacovino. Chodzi o metody badania powiązań pomiędzy prowadzeniem/chronieniem dokumentacji (recordkeeping) a etyką i prawem ${ }^{35}$. Na wstępie przytacza ona pogląd Franka Upwarda, który podkreśla, że archiwistyka była fundamentem, na którym zbudowano wiedzę o prowadzeniu dokumentacji. W tym kontekście niezbędna jest

${ }^{33}$ K. Skupieński, Kształcenie zarządców dokumentacji w Uniwersytecie Marii Curie-Skłodowskiej w Lublinie - podstawy koncepcyjne programu ksztatcenia, [w:] Zarzadzanie dokumentacja. Badania i dydaktyka, red. R. Degen i M. Jabłońska, Toruń 2016, s. 155-167.

${ }^{34}$ H. Booms, H. Joldersma, R. Klumpenhouwer, Society and the Formation of a Documentary Heritage: Issues in the Appraisal of Archival Sources, „Archivaria”, vol. 24 (Summer 1987), s. 69107, https://archivaria.ca/archivar/index.php/archivaria/issue/view/383 [dostęp: 25.10.2018].

${ }^{35}$ L. Iacovino, Multi-Method Interdisciplinary Research In Archival Science: The Case Of Recordkeeping, Ethics And Law, „Archival Science” 2004/4, s. 267-286, https://link.springer.com/ article/10.1007/s10502-005-2595-7 [dostęp: 11.09.2018]. 
refleksja także nad wiedzą narosłą $\mathrm{w}$ dyscyplinach, które mają znaczenie dla funkcjonowania dokumentacji. Livia Iacovino powołuje się następnie na Lucianę Duranti, która uważa, że archiwistyka powinna przede wszystkim odnowić swe silne więzi z prawem, z którym ma - genetycznie zwłaszcza poprzez dyplomatykę pojmowaną jak nauka o dokumencie - silne historyczne powiązania. Iacovino za Wendy Duff podkreśla też, ,że archiwiści oraz records managerowie, aby zajmować należne im miejsce regulatorów wymagań (requirements) dokumentacyjnych organizacji, muszą wykroczyć poza własną literaturę fachową i zrozumieć potrzeby innych zawodów, oraz w ogóle społeczeństwa, dotyczące prowadzenia dokumentacji”" ${ }^{\prime 3}$. Warto tu nadmienić, że autorka omawia też wyniki badawcze prawa oraz etyki.

Należy zgodzić się również ze stwierdzeniem o pierwszorzędnym znaczeniu prawa dla archiwistyki. Jak pamiętamy, klasycy polskiej archiwistyki, tacy jak Bohdan Ryszewski czy Czesław Biernat, nie wpisali prawa na listę dyscyplin naukowych związanych $\mathrm{z}$ archiwistyką. W tym samym kierunku szedł zresztą wcześniej Kazimierz Arłamowski, który raczej wyłączał z archiwistyki nawet „historię ustroju, historię kancelarii i organizację biurowości” ${ }^{37}$. Warto tu nieco rozwiąc tylko jeden wątek powiązań archiwistyki z prawem. Szczególnie interesujący wydaje się kierunek, którym podążały myśli Luciany Duranti ${ }^{38}$. Przytoczmy jej stwierdzenie znaczące dla tych wywodów: „Zostało to wielokrotnie powiedziane, że dla archiwisty dyplomatyka jest dyscypliną kształtującą (formative). Jej funkcja jest taka sama, jak anatomii dla lekarza, fizyki dla inżyniera i gramatyki dla lingwisty lub osoby piśmiennej”"39. Duranti nie ma przy tym wątpliwości, że „przez wieki centrum (ogniskiem) dyplomatyki pozostawał dokument archiwalny, zapis ucieleśniający czynność"40. Chodzi o czynność prawną. Dla prawidłowego określania przedmiotu archiwistyki duże znaczenie ma prawna koncepcja dokumentu jako prawomocnego dowodu. Właściwe określenie, na czym polega sam trzon fundamentu, z którego wznosi się skomplikowana struktura gmachu archiwistyki, jest ważne dla rozważań o jej interdyscyplinarności. Powyższe wydaje się wskazywać, że ów trzon czy może sedno, to dokument przede wszystkim w ujęciu, które już w XIX w. głównie niemiecka dyplomatyczna szkoła historyczno-prawna

${ }^{36}$ Ibidem, s. 268.

${ }^{37}$ Zob. przyp. 24.

${ }^{38}$ K. Skupieński, Pytania o „,causae bellorum diplomaticorum”...; idem, Od metod dyplomatyki ku metodologii badań nad dokumentowaniem. Luciana Duranti o fakcie, akcie i dokumencie w biurokracji, [w:] Dzieje biurokracji, t. 6, pod red. T.A. Bykowej, A. Góraka i G. Smyka, Lublin 2016, s. $43-56$.

${ }^{39}$ L. Duranti, Diplomatics: New Uses for an Old Science (Part VI), „Archivaria”, vol. 33 (Winter 1991-92), s. 7, https://archivaria.ca/index.php/archivaria/article/viewFile/11795/12746 [dostęp: 13.09.2018]. Odsyłacz do cytowanego zdania wymienia przykładowo wypowiedzi Giorgio Cencettiego i Jamesa O’Toole'a.

${ }^{40}$ Ibidem, s. 6. 
zapożyczyła od nauk właśnie prawnych i nader owocnie rozwinęła na gruncie nauki o dokumencie.

Przytoczone poniżej przykłady skuteczności prądów interdycyplinarnych mogą być inspirujące. Heather MacNeil, autorkę pierwszego artykułu Archiwoodmienność: ponowne przemyślenie pierwotnego porzadku ${ }^{41}$, interesuje kwestia autentyczności, a więc jednego z fundamentu badań nad dokumentem. Porównaniu podlega tradycyjna krytyka tekstu literackiego i klasyczna teoria klasyfikacji archiwalnej. Autorka uważa, że nawet jeśli obiekty ich analizy są różne, to dotyczą kwestii związanych z autentycznością. Innego rodzaju tekst stanowi wstęp do materiałów z konferencji, pn. „Memory, Identity and the Archival Paradigm: an interdisciplinary approach", która odbyła się w $2010 \mathrm{r}^{42}$ Tu pojawia się m.in. wątek nowej roli archiwistów, którzy wypadając z roli bezstronnych kustoszy zasobu, zaczynają odgrywać rolę aktywnie kształtujących i reinterpretujących archiwalia, a co za tym idzie także pamięć i historię. Kolejny artykuł intryguje już samym tytułem - Świat Hannah Arendt: biurokracja, dokumentacja i banalne zto ${ }^{43}$. Ciekawym też może się wydać cytat z abstraktu: „Ten tekst stosuje teorię Hannah Arendt dotyczącą banalności zła do dokumentacji i praktyk zarządzania dokumentami [...] Koncepcja zła Arendt rzuca wyzwanie archiwistom [...] i przypomina nam, abyśmy nie stawali się wspólnikami biurokracji śmierci”. Ostatni przykład nosi niemniej frapujący tytuł: Krzyżówka bibliotekarza z historykiem: wyobrażenie archiwistów w filmach. Chodziło oczywiście o stereotyp archiwistów, zgodnie z którym są oni „zakurzeni, staromodni i nieszczęśliwi” ${ }^{4}$. Skojarzenia z bibliotekarzem w końcu odrzucono. W filmach archiwiści zwykle jednak odpowiadają rozpowszechnionym stereotypom na temat ich powierzchowności i zachowania.

\section{Bibliografia}

Aldred T., Burr G., Park E., Crossing a Librarian with a Historian: The Image of Reel Archivists, „Archivaria”, vol. 66 (Fall 2008), s. 57-93.

Arłamowski K., Archiwistyka, jej natura i definicja, „Archeion” 1970, t. 53, s. 7-26.

Biernat Cz., Problemy archiwistyki współczesnej, Warszawa 1977.

Booms H., Joldersma H., Klumpenhouwer R., Society and the Formation of a Documentary Heritage: Issues in the Appraisal of Archival Sources, ,Archivaria”, vol. 24 (Summer 1987), s. 69107, https://archivaria.ca/archivar/index.php/archivaria/issue/view/383 [dostęp: 25.10.2018].

${ }^{41}$ H. MacNeil, Archivalterity: Rethinking Original Order, „Archivaria”, vol. 66 (Fall 2008), s. 1-24; tekst do wyszukania tu: https://archivaria.ca/index.php/archivaria/issue/archive.

${ }^{42}$ C. Brown, Memory, identity and the archival paradigm: introduction to the special issue, „Archival Science”, 2013/13, s. 85-93, https://link.springer.com/article/10.1007/s10502-013-9203-z [dostęp: 22.08.2018].

${ }^{43}$ M. Caswell, Hannah Arendt's World: Bureaucracy, Documentation, and Banal Evil, „Archivaria”, vol. 70 (Fall 2010), s. 1-25 (zob. wyżej przypis 41).

${ }^{44}$ T. Aldred, G. Burr, and E. Park, Crossing a Librarian with a Historian: The Image of Reel Archivists, „Archivaria”, vol. 66 (Fall 2008), s. 57-93 (zob. wyżej przyp. 41). 
Brown C., Memory, identity and the archival paradigm: introduction to the special issue, „Archival Science”, 2013/13, s. 85-93, https://ink.springer.com/article/10.1007/s10502-0139203 [dostęp: 22.08.2018].

Caswell M., Hannah Arendt's World: Bureaucracy, Documentation, and Banal Evil, „Archivaria”, vol. 70 (Fall 2010), s. 1-25.

Duranti L., Diplomatics: New Uses for an Old Science (Part VI), „Archivaria” 33 (Winter 199 1-92), s. 7, https://archivaria.ca/index.php/archivaria/article/viewFile/11795/12746 ([dostęp: 13.09.2018].

Educating for the Archival Multiverse. The Archival Education and Research Institute (AERI), Pluralizing the Archival Curriculum Group (PACG), „The American Archivist”, vol. 74 (Spring/ Summer 2011), s. 73, http://americanarchivist.org/doi/10.17723/aarc.74.1.hv33964712745684 [dostęp: 25.11.2018].

Gara J., Idea transcyscyplinarności i interdyscyplinarna natura wiedzy pedagogicznej, „Forum Pedagogiczne", 2014, nr 1, s. 35-54, http://bazhum.muzhp.pl/media//files/Forum_Pedagogiczne/Forum Pedagogiczne-r2014-t1/Forum_Pedagogiczne-r2014-t1-s35-54/Forum_Pedagogiczne-r2014-t1-s35-54.pdf, [dostęp: 01.09.2018].

Grygier T., Zarząd aktami - problem centralny archiwistyki wspótczesnej, „Archiwa, Biblioteki i Muzea Kościelne” 1978, t. 36, s. 21-59.

Hvidtfeldt R., The Structure of Interdisciplinary Science, Cham 2018.

Iacovino L., Multi-Method Interdisciplinary Research In Archival Science: The Case of Recordkeeping, Ethics And Law, „Archivea Science”, vol. 4, 2004, pp. 267-286.

Karczewski M., Czy politologia to „,nauka interdyscyplinarna”? Kilka słów o przedmiocie poznania i tożsamości dyscypliny, „Refleksje” 2013, nr 7, s. 159-170, https://repozytorium.amu.edu. pl/bitstream/10593/10526/1/Maciej\%20Karczewski.pdf [dostęp: 27.08.2019].

Macneil H., Archivalterity: Rethinking Original Order, „Archivaria”, vol. 66 (Fall 2008), s. 1-24, https://archivaria.ca/index.php/archivaria/issue/archive [dostęp: 25.08.2019].

Magier D., Czas archiwozofii, [w:] Teoria archiwalna wczoraj - dziś - jutro, Toruńskie Konfrontacje Archiwalne, t. 2, red. W. Chorążyczewski, A. Rosa, Torun 2011, s. 9-20.

Mazur H., Między dydaktyka a archiwistyką. Interdyscyplinarność archiwistyki w kontekście edukacyjnej funkcji archiwów, [w:] Nowa archiwistyka - archiwa i archiwistyka w ponowoczesnym kontekście kulturowym, Toruńskie Konfrontacje Archiwalne, t. 4, red. W. Chorążyczewski, W. Piasek, A. Rosa, Toruń 2014, s. 163-187.

McKemmish S., Gilliland A., Archival and recordkeeping research: past, present and future, [w:] Research Methods: Information, Systems, and Contexts, red. K. Williamson, G. Johanson, Prahran 2013, https://pdfs.semanticscholar.org/a6c0/26f7d2aa25e44b751620ae0854a657fce3d8.pdf [dostęp: 21.11.2019].

Nowożycki B., Teoria i praktyka archiwistyki USA, Warszawa 2017.

Ortega y Gasset J., Bunt mas, przeł. P. Niklewicz, Warszawa 2002, https://filspol.files.wordpress. com/2009/10/ortega-y-gasset-jose-bunt-mas.pdf [dostęp: 29.08.2018].

Piasek W., Archiwistyka - jedna czy wiele dyscyplin naukowych? Uwagi z perspektywy „nowej archiwistyki”, [w:] Pogranicza archiwistyki, Toruńskie Konfrontacje Archiwalne, t. 6, red. W. Chorążyczewski, A. Rosa, Torun 2019, s. 25-31. 
Rancière J., Thinking between disciplines: an aesthetics of knowledge, transl. J. Roffe, „Parrhesia” 2006, nr 1, s. 1-12.

Research in the Archival Multiverse, ed. A.J. Gilliland, S. McKemmish, A.J. Lau, Monash University Publishing 2017, https://www.oapen.org/download?type=document\&docid=628143 [dostęp: 10.09.2018].

Robótka H., Ryszewski B., Tomczak A., Archiwistyka, Warszawa 1989.

Ryszewski B., Problemy i metody badawcze archiwistyki, Toruń 1985.

Sierpowski S., Interdyscyplinarna archiwistyka, „Archeion” 2003, t. 105, s. 42-45.

Skupieński K., Od metod dyplomatyki ku metodologii badań nad dokumentowaniem. Luciana Duranti o fakcie, akcie i dokumencie w biurokracji, [w:] Dzieje biurokracji, t. 6, pod red. T.A. Bykowej, A. Góraka i G. Smyka, Lublin 2016, s. 47-59.

Skupieński K., Kształcenie zarządców dokumentacji w Uniwersytecie Marii Curie-Skłodowskiej w Lublinie - podstawy koncepcyjne programu ksztatcenia, [w:] Zarzadzanie dokumentacja. Badania i dydaktyka, red. R. Degen i M. Jabłońska, Toruń 2016, s. 155-167.

Skupieński K., Pytania o „causae bellorum diplomaticorum” w XXI wieku. Od dyplomatyki mediewistycznej do Records Management, [w:] Belliculum diplomaticum VI Thorunense. Od dyplomatyki i archiwistyki do dokumentu elektronicznego, pod red. K. Kopińskiego i J. Tandeckiego, Toruń 2016, s. 83-103.

Tabaszewska J., „,Wędrujące pojęcia”. Koncepcja Mieke Bal-przyklad inter-czy transdyscplinarności?, „Studia Europaea Gnesnensia”, 2013, t. 8, s. 113-130, http://bazhum.muzhp.pl/ media//files/Studia_Europaea_Gnesnensia/Studia_Europaea_Gnesnensia-r2013-t8/Studia Europaea_Gnesnensia-r2013-t8-s113-130/Studia_Europaea_Gnesnensia-r2013-t8-s113-130. pdf [dostęp: 25.08.2018].

Transdyscyplinarność badań nad komunikacją medialna, red. M. Kita, M. Ślawska, t. 1-3, Katowice 2012-2013.

The Oxford Handbook of Interdisciplinarity, ed. by R. Frodeman, Oxford 2019.

The Philosophy of the Archive. Papers from the Conference held in Edinburgh, 10-11 April, 2008, ed. P. Whatley, C. Brown, „Archival Science”, vol. 9, Issue 3-4, December 2009.

Woleński J., O wewnętrznej i zewnętrznej integracji nauk, „Zagadnienia Naukoznawstwa” 2016, t. 52, z. 1, s. 5-14, https://www.infona.pl/resource/...374b.../f77c03c8-b28e-31da-a9f6-f0a0ffd065e2 [dostęp: 29.08.18]. 